\title{
SPECIFIC FEATURES OF USING HISTORICAL AND CULTURAL RESOURCES OF THE UKRAINIAN-POLISH BORDERLAND FOR TOURISM PURPOSES
}

The present article is dedicated to the investigation of an important part of tourist resources of the Ukrainian and Polish borderland, namely, the unique monuments of its material culture. It analyses the main historic and cultural reasons of appearing monuments on this territory, the distribution of these monuments among administrative units (rayons and poviats) with their representation on a diagram. The diagram was based on Ukraine and Polish Lists of Monuments. The article also studies the structure of the historic and cultural resources: the stationary monuments of history, architecture, city-planning, reserved castles and objects of lanscape gardening art etc. Among all the resources it descripes monuments and architectural complexes on the UNESCO List. Also, it analyses the tourist itineraries functioning on the territory of the Ukrainian and Polish borderland. Main itineraries were taken from the tourist maps of Lviv, Volyn, Lubelskie and Podkarpackie regions. Also it proposes several new cross-border itineraries, which can potentially satisfy the demand on meaningful rest and generating tangible revenues on this territory.

Based on results of the research the following conclusions have been made: Ukrsinian-Polish border area is reach in historical and cultural resources, but they are not popularized enough; The territory of investigation has many attractive tourist routs, which can satisfy different requirements, but they also need to be promoted.

Keywords: Ukrainian and Polish borderland, historic and cultural resources, stationary monuments, tourist itineraries (routs), cross-border itineraries.

Степан Кузик, Дарина Литвин. ОСОБЛИВОСТІ ВИКОРИСТАННЯ ДЛЯ ТУРИСТИЧНИХ ЦІЕЙ ІСТОРИКОКУЛЬТУРНИХ РЕСУРСІВ УКРӒ̈НСЬКО-ПОЛЬСЬКОГО ПРИКОРДОННЯ

Стаття присвячена аналізу історико-культурних ресурсів українсько-польського прикордоння, які у даному дослідженні представлені нерухомими пам'ятками. Окреслено головні чинники виникнення даних пам'яток на території прикордоння, а також подано їхню класифікацію згідно українського і польського законодавства. На основі державних реєстрів пам'яток розроблено картосхему їхнього поширення у розрізі районів та повітів. Здійснено короткий опис тих пам'яток прикордоння, які мають статус об'єктів Світової спадщини ЮНЕСКО. За допомогою туристичних мап проаналізовано головні туристичні маршрути у розрізі областей та воєводств, а також запропоновано нові транскордонні маршрути.

Ключові слова: українсько-польське прикордоння, історико-культурні ресурси, нерухомі пам’ятки, туристичні маршрути, транскордонні туристичні маршрути.

Степан Кузык, Дарина Литвин. ОСОБЕННОСТИ ИСПОЛЬЗОВАНИЯ В ТУРИСТИЧЕСКИХ ЦЕЛЯХ ИСТОРИКО-КУЛЬТУРНЫХ РЕСУРСОВ УКРАИНСКО-ПОЛЬСКОГО ПРИГРАНИЧЬЯ

Статья посвящена анализу историко-культурных ресурсов на территории украинско-польского приграничья, которые в данном исследовании представлены недвижимыми памятками. Очерчены главные факторы возникновения памяток на территории приграничья, а также подана их классификация согласно с украинским и польским законодательством. На основании национальных реестров памяток разработана картосхема их распространения в разрезе районов и поветов. Осуществлено краткое описание тех памяток, которые имеют статус объектов Всемирного наследия ЮНЕСКО. С помощью туристических карт проанализированы главные туристические маршруты в разрезе областей и воеводств, а также предложены новые трансграничные маршруты.

Ключевые слова: украинско-польское приграничье, историко-культурные ресурсы, недвижимые памятки, туристические маршруты, трансграничные туристические маршруты.

1. Introduction. Historical and cultural resources these are the monuments of material and spiritual culture created along the historical development of society, they are of cognitive value and can serve as factors in tourism development in a particular area. The role of these resources in tourism and recreation has been studied by famous scientists in Ukraine Oleksandr Beidyk (2001), Petro Masliak (2008), Halyna Bovsunovska (2002), Oleh Shabliy (2012), Stepan Kuzyk (2010) et al. In their view, historical and cultural resources play an important role in shaping tourist demand, creating an attractive tourist image of the region or the state, and ultimately contribute to their economic growth. Each area or region is characterized by a unique history, culture and traditions. This attracts tourists, satisfies their need for knowledge of the world and meaningful vacation. According to the World Tourism Organization (UNWTO), Tourism is one of the world's largest and fastest growing export sectors, contributing to $9 \%$ of the global GDP, and accounts for one in eleven jobs worldwide (Global Report..., 2017).

Our research is designed to identify and compare historical and cultural resources of border regions of Ukraine and Poland, to determine the possibility and extent of their use for tourism purposes. The study area covers two border regions of Ukraine - Lviv and Volyn and neighboring regions of Poland - Lubelskie and Podkarpackie.

It should be noted that the regions have been inhabited by man since ancient times, which means that they retain the monuments and artifacts from different eras. 
Secondly, at various times the border between the states was not fixed, and Poland and Ukraine were losing their independence for some period of time and it also resulted in the appearance or disappearance of some historical and cultural sites. By the way, being under the control of other countries do not always mean the decline of material culture. For example, during the reign of Franz Joseph II Lviv got entire blocks of the so-called Viennese buildings, which now creates unique architectural ensemble of the city. Another important feature of this area is that at different times, in addition to Ukrainians and Polish, it was inhabited by Jews, Germans and other nationalities. This contributed to cultural diversity, coexistence of different believes and religions, and traditions embodied in celebration of the holidays, housing, clothing decoration, spread of crafts of certain ethnic groups. Thus, the development of this ancient territory, rich history and varied national and ethnic composition of the population are the factors that led to the creation of unique and diverse monuments, history, archeology, folklore, etc.

2. Immovable historical and cultural monuments. The area of our study is enough large for tourism investigation, so it is advisable to use a generalization method. One of the generalization ways may be comparing the number of monuments in rayons and poviats as well as cities of oblast and voivodeship importance.

First of all, we need to give definition of the term "monument". According to the Law of Ukraine "On Protection of Cultural Heritage" monument is an object of cultural heritage on the State List of Ukraine (Про занесення об'єктів..., 2017).; The object of cultural heritage means a landmark, building (creation), complex (ensemble), their parts, associated movable objects, as well as territory or water area (objects of underwater and archaeological cultural heritage), other natural, naturaland-man-made or man-made objects regardless of the state of preservation that brought the value of archaeological, aesthetic, ethnological, historical, architectural, artistic, scientific or artistic point of view and maintained their authenticity till our times. By the type, cultural heritage sites are divided into: archaeological, historical, monumental art objects, architecture objects, urban planning objects, landscape architecture objects, landscape gardening objects, objects of science and technology. The equivalent Polish document (Ustawa o ochronie..., 2017) gives the following definition: monument - is an immovable or movable thing, their parts or complexes which, being a creation of a man, or result of related activities, constitute evidence of a bygone era or event and their preservation is in the public interest in terms of historical, artistic or scientific value. In both laws monuments are divided into movable and immovable. In our study only immovable sites are taken into account. In Poland, just like in Ukraine, these include cultural landscapes, urban and rural development, complexes of buildings, works of architecture and construction, including defense, technical objects, especially mines, glassworks, power plants and other industrial facilities, cemeteries, parks, gardens and other forms of designing green spaces, places that cherish memories of important events or activities of outstanding personalities or institutions.
3. Features of historical and cultural resources location. The monuments were recorded as of 2016, according to the Monuments Registers which in Ukraine and Poland are maintained by the state organizations for the protection of cultural heritage (Rejestr Zabytków..., 2017; Wykaz zabytków..., 2017). On its basis, a map was created (Fig. 1). It is clear that monuments are located throughout the border zone, but in Lvivska oblast on and Podkarpackie voivodeship they are visually more numerous. Thus, Lvivska oblast is taking first place in terms of this indicator $(5,407)$, Podkarpackie voivodeship - the second place $(2,973)$, the third place is taken by Lubelskie voivodeship $(1,915)$ and Volynska oblast has slightly fewer monuments $(1,505)$. If we compare cities of voivdeship and regional importance, Lviv has the undeniable advantage in terms of a number of monuments $(2,404)$. It is the only city in Ukraine which is ahead of all others in this category. Thus, one could argue that Lviv is the largest historical and cultural center not only of this territory.

If we consider this figure in terms of rayons and poviats, we can highlight the areas with the biggest and smallest number of monuments. The largest by number of monuments in the border area is Przemyski poviat (572) of Podkarpackie voivodeship, mainly due to Przemyśl city, which has more than 350 monuments, the next largest is Zhovkivskyi and Drohobytskyi rayons of Lvivska oblast (338 and 320 respectively) with historical and cultural centers such as Zholkva and Drohobych.

Significant in terms of the number of monuments (200 to 300) in the Lvivska oblast is Stryiskyi rayon, in Podkarpackie voivodeship - Krośnieński and Jarosławski poviats with the centers Jarosław and Krosno, and in Lubelskie voivodeship - Zamojski and Puławski poviats with the cities Zamość, Kazimierz Dolny, Nałęczów, Puławy.

There are from 100 to 200 monuments in Lvivska oblast: Sambirskyi, Peremyshlianskyi, Zhydachivskyi, Sokalskyi, Zolochivskyi, Buskyi, Starosambirskyi, Pustomytivskyi, Kamianka-Buzkyi, Yavorivskyi and Skolivskyi rayons; in Volynska oblast: Horokhivskyi, Volodymyr-Volynskyi, Manevytskyi, Kovelskyi, Turiyskyi, Kivertsivskyi rayons; in Podkarpackie voivodeship: Lubaczowski, Łańcucki, Sanocki, Rzeszowski and Przeworski poviats; and finally, in Lubelskie voivodeship is Bialski, Hrubieszowski, Chełmski, Tomaszowski and Lubelski poviats.

The lowest number of monuments can be found in Janowski, Świdnicki, Łęczyński and Rycki poviats (up to 30 monuments in each one) of Lubelskie voivodeship.

Of course, this approach is somewhat simplistic in providing the information available and it is not always possible to assess the area's tourism potential by the number of monuments only. After all, a town or village might have only one monument, but it might be very appealing and attract a large number of people. In Lubelskie voivodeship, this city is Kozłówka in Lubartowski poviat where there is only one site - 1735-42 Palace. However, interiors of the palace are perfectly preserved, magnificent park and scenic surroundings in this locality attract many tourists. 


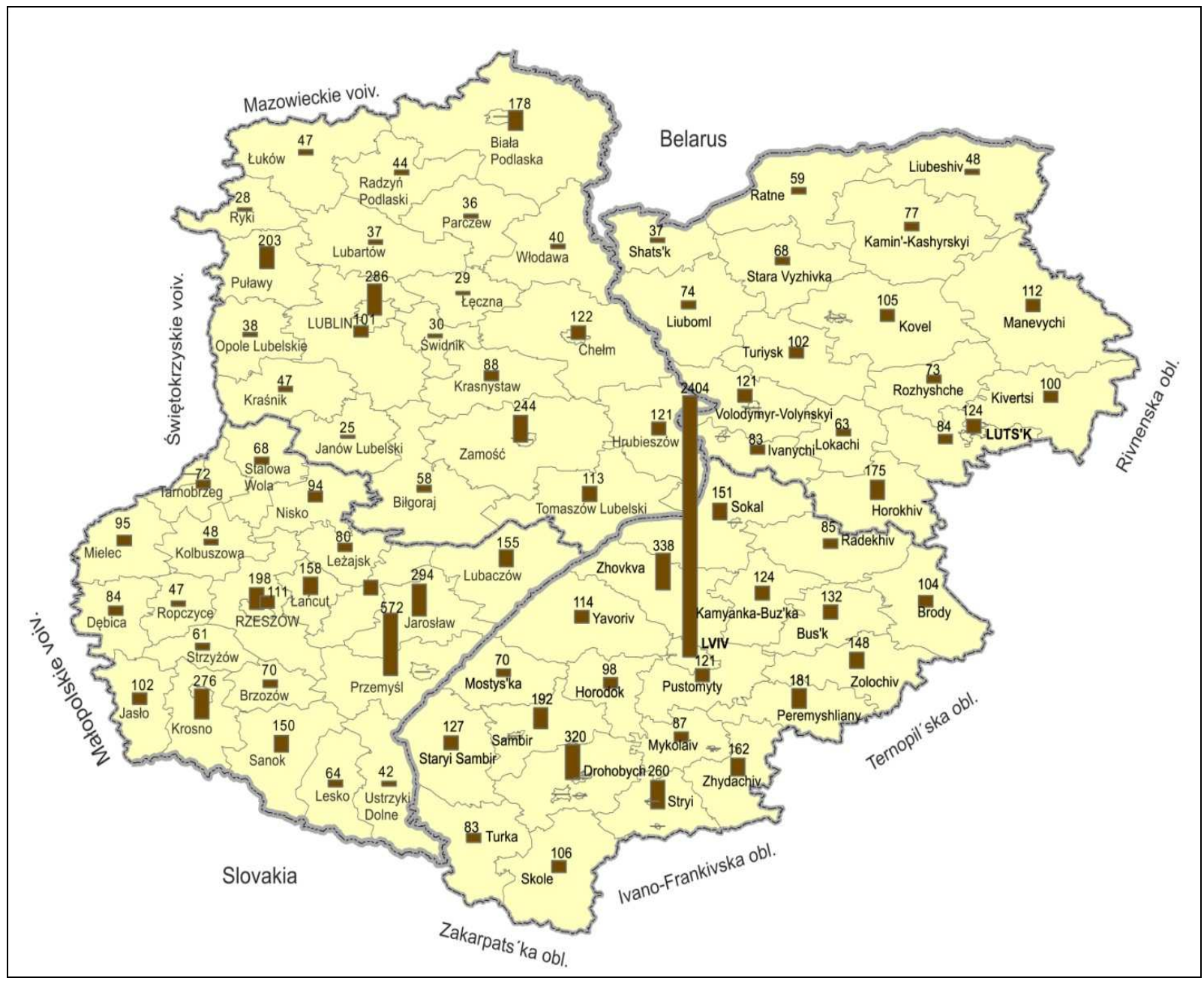

Fig. 1. Stationary monuments in Ukrainian and Polish borderland (2016)

Table 1

\section{Monuments and architectural complexes of Ukrainian-Polish border area on the UNESCO List}

\begin{tabular}{|c|c|c|c|}
\hline No. & Settlement & Oblast / Voivodeship & UNESCO Site \\
\hline 1 & Zamość & Lubelskie & $\begin{array}{l}\text { Renaissance buildings of the Old Town (Rynok Square and } \\
\text { vicinity) }\end{array}$ \\
\hline 2 & Lviv & Lvivska & Ensemble of the historic center of 13th-18th century. \\
\hline 3 & $\begin{array}{l}\text { Potelych (Zhovkivskyi } \\
\text { rayon) }\end{array}$ & Lvivska & $\begin{array}{l}\text { Holy Spirit wooden church } 1502 \text {, the oldest wooden three- } \\
\text { section church in Ukraine }\end{array}$ \\
\hline 4 & $\begin{array}{l}\text { Matkiv (Turkivskyyi } \\
\text { rayon) }\end{array}$ & Lvivska & wooden church Virgin Mary Cathedral, 1838 \\
\hline 5 & Zhovkva & Lvivska & Holy Trinity wooden church, 1720 \\
\hline 6 & Drohobych & Lvivska & St. George wooden church, 1502 \\
\hline 7 & $\begin{array}{l}\text { Blizne (Brzozowski } \\
\text { poviat) }\end{array}$ & Podkarpackie & $\begin{array}{l}\text { wooden church and clergy house complex second half of the } \\
15 \text { th century. }\end{array}$ \\
\hline 8 & $\begin{array}{l}\text { Haczów (Brzozowski } \\
\text { poviat) }\end{array}$ & Podkarpackie & $\begin{array}{l}\text { Assumption of the Virgin Mary and Saint Michael the Arch- } \\
\text { angel wooden church }\end{array}$ \\
\hline 9 & $\begin{array}{l}\text { Turzańsk (Sanocki } \\
\text { poviat) }\end{array}$ & Podkarpackie & $\begin{array}{l}\text { Saint Michael the Archangel wooden church, Greek-Catholic, } \\
1801-1803 \text {, rebuilt in } 1898 \text { and } 1913\end{array}$ \\
\hline 10 & $\begin{array}{l}\text { Smolnik (Sanocki } \\
\text { poviat) }\end{array}$ & Podkarpackie & $\begin{array}{l}\text { former Greek-Catholic Saint Michael the Archangel wooden } \\
\text { church, 1791, Catholic Assumption of the Virgin Mary Ca- } \\
\text { thedral }\end{array}$ \\
\hline 11 & $\begin{array}{l}\text { Chotyniec } \\
\text { (Jarosławski poviat) }\end{array}$ & Podkarpackie & $\begin{array}{l}\text { Nativity of Mary wooden church, 1615, iconostasis - 1671, } \\
\text { now Greek-Catholic church }\end{array}$ \\
\hline 12 & $\begin{array}{l}\text { Radruż (Lubaczowski } \\
\text { poviat) }\end{array}$ & Podkarpackie & $\begin{array}{l}\text { St. Paraskeva wooden church the first half of the } 16^{\text {th }} \text { century, } \\
\text { the oldest and best preserved wooden church in Poland }\end{array}$ \\
\hline
\end{tabular}


Worldwide, an important appeal criterion is the fact that the site or complex is on the UNESCO World Heritage List. In the Ukrainian-Polish border zone, there are two architectural ensembles of the cities of Lviv and Zamość and ten wooden churches and cathedrals on the list, 8 of which were listed as a result of the UkrainianPolish project "Wooden Churches of the Ukrainian and Polish Carpathians" in 2013. This amount of monuments on the UNESCO list could serve as an important factor for the promotion of tourism and creation of new transborder routes "UNESCO Sites".

Among all immovable monuments in the study area, the most numerous are architectural monuments. Therefore we will briefly describe them. The most attractive buildings are castles, palaces and residences, which are quite widespread in the Ukrainian-Polish border zone. The most famous castles in Lvivska oblast - in Olesko, Zolochiv, Pidhirtsi, Zhovkva, Svirzh, Pomoryany, in Volynska oblast - in Lutsk and Olyka, in Lubelskie voivodeship - in Lublin, Biała Podlaska, Czemierniki, Janowiec, in Podkarpackie voivodeship Łańcut, Dukla, Lesko, Baranów Sandomierski, Dzików, Przemyśl, Krasiczyn, Dubiecko, Sanok (the largest in Poland). The significant difference between the Ukrainian and Polish castles is their level of preservation. Thus, on the Ukrainian territory there is no castle with preserved authentic interior, however, some of them are nicely furnished with museum exhibits of different ages (Olesko, Zolochiv). At the Ukrainian-Polish border zone, there is also a lot of castle ruins and remains of walls and fortifications which indicate that there used to be a castle.

In addition to castles, former residences and palaces also attract tourists. The main families that left behind magnificent palaces and parks, and beautiful residences were the Sobieskyis, the Zamoiskyis, the Seniavskyis, the Firleis, the Liubomyrskyis, the Mnisheks, later the Pototskyis and Sanhushkos, families of Ukrainian origin the Didushytskyis and the Sapihas, German barons Hrodli and others. These palaces can be visited in Lviv, Zhuravno, Busk, Rozdil, Demnya Lvivska oblast; Nozdrzec, Czarna, Narol, Olszanica, Horyniec-Zdrój, Leżajsk, Mielec, Rozwadów, Przeworsk, Rzeszów of Podkarpackie voivodeship and Kozłówka, Lubartów, Nałęczów, Dęblin, Jabłoń, Radzyń Podlaski, Rejowiec, Hrubieszów, Kock, Opole Lubelskie, Dołhobyczów of Lubelskie voivodeship.

Sacred tourism should become equally popular tourism area because every district and county of the border area has at least a few sacred monuments of national or regional significance. Religious buildings of Ukrainian-Polish border zone include churches, synagogues and the German churches. The oldest of the churches are located in famous cities - VolodymyrVolynskyi (Assumption Cathedral, 1156-1160), Lviv, the so-called "city of a hundred churches", Chełm, Lublin, Przemyśl. Of special cultural value are the border area wooden monuments of sacred architecture. The oldest authentic wooden church in Ukrainian border area is the above-mentioned Potelych village church, Zhovkivsky rayon. In Poland this is Lemko wooden church in the village of Ulucz (near Sanok), a monument of the 17 th century. The unique and diverse architecture of wooden buildings is focused on both sides of the border and has unique features depending on location at some ethnographic territory. In particular, there are wooden Lemko, Boiko churches, there are churches with elements of Hutsul architecture (however, Hutsulshchyna is not covered in the study), Volyn wooden churches unique in terms of construction and appearance. It should be noted that the preservation of these wooden monuments should be a priority as wood is a material that burns easily and can be damaged under improper storage conditions. Another threat to the wooden monuments is unauthorized violation of their authentic state, which is becoming really dangerous, especially in Lvivska oblast. In particular, this includes replacement of wooden shingles with metal, roof reconstruction and other building and finishing works distorting the original appearance of the church and questioning the preservation of its authenticity. An important task is the creation of a single register of wooden churches of the Polish-Ukrainian border zone as it would greatly help in preserving and popularizing this original and unique architecture. In the Polish border zone, in addition to wooden Lemko churches, there are distinctive and unique wooden catholic churches. Undoubtedly, voivodeship and regional centers and major cities are characterized by the greatest number of sacred sites.

Noteworthy are also sacred buildings of significant in terms of number peoples that had lived in the border zone, primarily Jews and Germans. Despite the fact that most synagogues were destroyed during the Second World War, in the border zone, old Renaissance synagogues were preserved - in Zhovkva, Lvivska oblast, Lutsk, Zamość Lubelskie voivodeship, in Rzeszów, the synagogues of later periods are much more numerous. As for the German temples, there are fewer of those (the most famous ones include Lutheran church in Lutsk, former German church in Vynnyky, village Pidhaichyky Zolochiv rayon, Lvivska oblast, etc.), However, in Lvivska and Volynska oblasts, there were many German settlements. As of 1914, in Volyn region, there were 600 German colonies with the population of about 200,000 people (Атлас історії культури..., 2008). In Halychyna, at the beginning of the 20th century, there were more than 100 German settlements (Петришин, 2008). Unlike Jews, Germans were living mainly in rural areas. They were engaged in agriculture and had high farming culture.

Historical and cultural sites of the border zone are located in different natural areas and regions and scenic nature complements the overall experience of visiting castles, churches, palaces or temples. In addition to the above attractions, tourists are also interested in ancient industry buildings, places of historical events, military fortifications, as well as areas associated with the life and work of prominent people. There are a lot of these sites in the border zone and the most famous of them are included in the regional tourist routes.

4. Analysis of existing and proposed tourist routes. In this study, we are making an attempt to classify existing routes by region and offer new, crossborder ones as we believe that the Ukrainian-Polish cooperation in tourism sphere is perspective. Analysis of the existing routes was performed based on the tourist 
maps of Lubelskie, Podkarpackie voivodeships and Lvivska oblast and site of the Department of Culture of Volyn Administration (Волинь туристична, 2012; Львів і область..., 2008; Тематичні шляхи..., 2008; Województwo Lubelskie, 2004). The picturesque nature and protected areas network resulted in the development of purely natural tourist routes in the border zone. One of these is the route called "Natural" going through the territory of Lubelskie voivodeship through the Polissia National Park and several landscape parks. On this route, you can see the rare species of protected plants and animals. Similar is the route "Reserve Paths of Polissia" in Volynska oblast with the Shatskyi National Park and Cheremskyi Nature Reserve.

Most of the routes are focused on a combination of historical, cultural and natural resources. They include "Nadvislianski", "Historical", "Museum" and "Tustan White Gold", "Belz Principality Pearls" routes and others.

Table 2

Current Ukrainian border zone routes and the proposed cross-border routes

\begin{tabular}{|c|c|}
\hline Name & Route \\
\hline \multicolumn{2}{|r|}{ Lvivska oblast } \\
\hline Golden Horseshoe & Lviv - Novyi Myliatyn - Busk - Olesko - Pidhirtsi - Sasiv - Zolochiv - Vynnyky - Lviv \\
\hline Silver Horseshoe & Lviv - Novyi Myliatyn - Olesko - Brody - Pidkamin \\
\hline Royal Zhovkva & Lviv - Kulykiv - Zhovkva - Krekhiv - Rava Ruska \\
\hline Picturesque Roztochchia & Lviv - Stradch - Ivano-Frankove - Prylbychi - Yavoriv - Volia Liubynska \\
\hline Pinzel and Fredro & $\begin{array}{l}\text { Lviv - Hodovytsya - Navariya - Pustomyty - Shchyrets - Hrimno - Klitsko - Komarno - } \\
\text { Rudky - Vyshnya - Velykyi Liubin - Obroshyno - Zymna Voda }\end{array}$ \\
\hline At the border of two seas & $\begin{array}{l}\text { Lviv - Stare Selo - Bibrka - Piatnychany - Svirzh - Peremyshliany - Univ - Zolochiv - } \\
\text { Pomoriany }\end{array}$ \\
\hline Prince Lev and St. Valentine & $\begin{array}{l}\text { Lviv - Obroshyno - Velyki Rudky - Sambir - Staryi Sambir - Lavriv - Khyriv - Dobromyl } \\
\text { - Skelivka - Susidovychi }\end{array}$ \\
\hline Tustan White Gold & Lviv - Mykolaiv - Drohobych - Urych - Korchyn - Rozhirche - Stryi - Mykolaiv - Lviv \\
\hline Visit to the White Croats & $\begin{array}{l}\text { Lviv - Zaklad - Mykolaiv - Stilsko - Dubrova - Berezdivtsi - Hnizdychiv - Zhydachiv - } \\
\text { Rozdil }\end{array}$ \\
\hline Belz Principality Pearls & Lviv - Zhovkva - Chervonohrad - Tartakiv - Sokal - Variazh - Belz \\
\hline \multicolumn{2}{|r|}{ Volynska oblast } \\
\hline Reserves Paths of Polissia & $\begin{array}{l}\text { Shatskyi NNP - Zhorany - Nechymne - Cheremskyi Nature Reserve - Okonski springs - } \\
\text { Lopaten tract - Tsuman }\end{array}$ \\
\hline Gold Diadem of Volyn & $\begin{array}{l}\text { Ustyluh - Volodymyr-Volynskyi - Zymne - Zahoriv - Zaturtsi - Torchyn - Lutsk - Piddub- } \\
\text { tsi - Olyka }\end{array}$ \\
\hline Unknown Polissia & Liuboml - Kovel - Ratno - Kamin Kashyrskyi - Lyubeshiv - Trostyanets \\
\hline \multicolumn{2}{|r|}{ Proposed cross-border routes } \\
\hline The life of Oleksandr Fredro & $\begin{array}{l}\text { Rzesów - Krosno - Sanok - Hoczew - Baligród - Cisna - Sambir - Yatvihy - Liubin Ve- } \\
\text { lykyi - Lviv - Pshemyshl - Yarosulav }\end{array}$ \\
\hline $\begin{array}{l}\text { The life of Good Soldier } \\
\text { Svejk }\end{array}$ & $\begin{array}{l}\text { Radoszyce - Komańcza - Wysoczany - Zagórz- Sanok- Rozpucie - Ropienka - Wojtkowa } \\
\text { - Krościenko - Sambir - Rudky - Velykyi Lubin - Lviv - Zhovtantsi - } \\
\text { Kolodno }\end{array}$ \\
\hline Roztochanskyi & $\begin{array}{l}\text { Kraśnik - Janów Lubelski - LKP Lasy Janowskie - Biłgoraj - Zwierzyniec - Roztoczański } \\
\text { Park Narodowy - Krasnobród - Susiec - Hrebenne - Rava Ruska - Potelych - Krekhiv - } \\
\text { Zhovkva }\end{array}$ \\
\hline UNESCO sights I & $\begin{array}{l}\text { Lviv - Drohobych - Matkiv - Khyriv - Sanok - Turzańsk - Smolnik - Haczów - Blizne - } \\
\text { Przemyśl - Lviv }\end{array}$ \\
\hline UNESCO sights II & Lviv - Zhovkva - Rava-Ruska - Potelych - Zamość - Radruż - Chotyniec - Lviv \\
\hline The life of King Danylo & Lviv - Belz - Chełm - Zamość \\
\hline The life of M. Verbytskyi & Jawornik - Strilky - Zavadiv - Młyny \\
\hline
\end{tabular}

A separate group consists of those routes that pass castles, palaces and residences. In Lvivska oblast, these include "Golden Horseshoe of Lviv", "Silver Horseshoe", "Royal Zhovkva", in Lubelskie voivodeship this is a trip to "Magnates' Residences", in Podkarpackie voivodeship - "The Liubomyrskyis' family nests".

Historical and cultural monuments of various ethnic groups can be combined into a group of sentimental routes. There are two of these - "Jewish Culture" and "Crossing Cultures". Along them, we can see not only the ancient synagogues in .( Kazimierz Dolny, Łęczna, Włodawa, Józefów etc., but also visit the concentration camp Maidanek in Liublin, Muslim cemetery in
Studzianka and Lebiedziew etc.

Of the total number of routes, there are the ones devoted to outstanding personalities. They include already existing "Pinzel and Fredro", "Prince Lev and St. Valentine" and proposed transboundary route "The life of Oleksandr Fredro" and "The life of Good Soldier Svejk." The latter originates in the Czech Republic, passes through Austria, Hungary, Slovakia, Poland and ends in Ukraine. The route dedicated to the famous Polish writer O.Fredro may be interesting not only for Polish, but also Ukrainians because he was the grandfather of one of the most famous figures of the Ukrainian Greek Catholic Church - Metropolitan Andrei Sheptytskyi. Noteworthy 
is also the tourist route dedicated to King Danylo and composer M. Verbytskyi (Table. 2). In the border zone, there are many towns and villages associated with famous public figures, writers, artists, so development of the new routes showing the lives of famous people serves not only informative, but also educational and patriotic purposes.

Rich sacral heritage allows us to create more new tourist routes. In Lubelskie voivodeship, there is "Church Path" and route "Sacred Architecture". Due to the fact that in 2013, ten wooden churches of the border area were put on the UNESCO World Heritage List, we can offer two cross-border routes "UNESCO Sites". Equally important for Ukrainians and Poles is pilgrimage to holy places. In the border zone, there are the following pilgrimage centers and places with miracle-working icons: Kodeń, Pratulin, Janów Podlaski, Leśna Podlaska of Lubelskie voivodeship, Lutsk, Zymne, VolodymyrVolynskyi of Volynska oblast, Lviv, Krekhiv, Univ, Stradch of Lvivska oblast.

Fans of local military history should be interested in the "Military Route" that runs through the Podkarpackie voivodeship. Along it, you can see the unique sites of defensive architecture of the two world wars. This defensive fortress of Przemyśl where there are a total of 60 forts and fortifications of "Molotov Line" built on the eve of the Soviet-German war.

Conclusions

Ukrainian-Polish border zone is an attractive tourist area, rich in historical and cultural resources which constitute the basis of architectural monuments. The most attractive ones include castles, palaces (residences), palaces with parks, ancient shrines, monuments of defensive arts. At present, these attractions are not popularized among the local population and globally.

In the border zone, there are several historical and cultural centers, including the largest ones by the number of monuments - Lviv, Przemyśl, Lublin, Drohobych, Jarosław, Zhovkva, Rzeszów, Zamość, Lutsk, Volodymyr-Volynskyi, Stryi, Krosno, etc.

UNESCO sites provide significant potential for tourism development. In this regard, it is advisable to develop two cross-border routes for exploring these sights (Lviv - Drohobych - Matkiv - Khyriv - Sanok Turzańsk - Smolnik - Haczów - Blizne - Przemyśl Lviv; Lviv - Zhovkva - Rava-Ruska - Potelych Zamość - Radruż - Chotyniec - Lviv). Wooden sacred buildings with unique architecture are of special attractive value along these routes. An important issue in the context of preserving these and other wooden churches and temples is to create a single register and comprehensive Ukrainian-Polish cooperation in this area.

In addition to the proposed UNESCO sites route, in the Ukrainian-Polish border zone, a number of other routes have been developed, the most attractive are complex routes ("Nadvislyanski", "Historical", "Museum", "Tustan White Gold", "Belz Principality Pearl" "Golden Horseshoe of Lviv", "Royal Zhovkva", "Magnates' Residences", etc.). No less interesting can be thematic routes ("Jewish Culture", "Pinzel and Fredro", "The life of King Danylo", etc.). However, all those routes require active promotion among both domestic and foreign tourists.

Due to the dynamic development of tourism in the world as an important sector of the economy, it is advisable to preserve the existing historical and cultural resources of the Ukrainian-Polish border zone, to attract academic, business and governmental institutions to the study and promotion of these resources and establish a Ukrainian-Polish cooperation at various administrative and territorial levels in this area.

\section{Список використаних джерел:}

1. Атлас історії культури Волинської області [Текст] / [відп. ред. Ф.В. Зузук; упоряд.: З.К. Карпюк, О.В. Антипюк]. - Луцьк: Волин. нац. ун-т ім. Лесі Українки, 2008. - 112 с.

2. Атлас України й сумежних країв / Під заг. ред. В. Кубійовича. Наукове товариство ім. Шевченка. - Львів, 1937. - 113 c.

3. Бейдик О.О. Рекреаційно-туристські ресурси України: Методологія та методика аналізу, термінологія, районування. - К.: ВПЦ «Київ. Ун-т», 2001. - 395 с.

4. Бовсуновская А.Я. География туризма: Учеб. пособие. - Донецк: Донец. ин-т турист. бизнеса, $2002 .-410$ с.

5. Волинь туристична // Управління культури і туризму Волинської державної адміністрації [Електронний pecypc]. - Режим доступу: http:/www.cult.voladm.gov.ua/index.php?section=tour\&page=5 [01.03.2012]

6. Дорош А. Швейк у Галичині // Галицька брама. - Львів: Центр Європи, 1996. - Вип.16. - С. 11-13.

7. Карта України. 1: 2000000 / В. Кубійович, А. Жуковський. - Мюнхен: Karl Wenschow GmbH, 1977.

8. Кузик С.П. Теоретичні проблеми туризму: суспільно-географічний підхід: монографія / Степан Кузик. Львів: Видавн. центр ЛНУ імені Івана Франка, 2010. - 254 с.

9. Львів і область. Туристична мапа / Губіліт І., Дикий І. - Львів: СПД ФО Губіліт І.В.

10. Львів: комплексний атлас / Шаблій О.І., Вісьтак О.І., Матковський С.О. - Київ: ДНВП «Картографія», 2012. -192 c.

11. Масляк П.О. Рекреаційна географія: Навч. посіб. - Київ: Знання, 2008. - 343 с.

12. Петришин Г. Німецькі колонії Галичини. - Львів: Манускрипт, 1996. - 464 с.

13. Про охорону культурної спадщини, закон // Відомості Верховної Ради (ВВР), 2000. - $39 .-333$ с.

14. Тематичні шляхи Підкарпатського воєводства / Допціюх А., Форнал К. - Жешув: Уряд маршалковський Підкарпатського воєводства. - 23 с.

15. Територія розселення українців у межах сучасної Польщі на середину XX ст. 1 : 325000 /, Дикий I. Дніпропетровськ: ТзОВ торговий дім «Луна Пак», 2008.

16. Шаблій О. Суспільна географія у двох книгах. Книга друга. Проблеми українознавства, регіоналістики, краєзнавства. - Львів: ЛНУ ім. Івана Франка, 2015. - 270 с. 
17. Tcebrykuv P. (2004). Voevudstvo Lubelske. Mapa turystychna 1:300000 [Lubelskie voevodeship]. Lublin: KARTPOL.

18. Ustava o ohrone zabytkuv I opece nad zabytkami, Dz. U. Nr 162/03, 1568 puzn. zm. 23 lipca 2003 r. [About monument protection and their care, Law, Dz. U. Nr 162/03, 1568 puzn. zm. 23 july 2003 r.]

19. Rejestr zabytków [Електронний pecypc]. - Режим доступу: http://www.nid.pl/pl/Informacje_ogolne /Zabytki_w_Polsce/rejestr-zabytkow/zestawienia-zabytkow-nieruchomych/stan\%20na\%2030.09.2016/PDK-rej.pdf

20. Wykaz zabytków nieruhomych I archeologicznych wpisanych do Rejestru zabytków w 2016. [Електронний ресурс]. - Режим доступу: http://wkz.lublin.pl/images/stories/Obwieszczenie_nr1_2016.pdf

21. Про занесення об'єктів культурної спадщини національного значення до Державного реєстру нерухомих пам'яток України. [Електронний ресурс]. - Режим доступу: http://zakon5.rada.gov.ua/laws/show/1805-14

22. Global Report on Food Tourism. [Електронний ресурс]. - Режим доступу: http://cf.cdn.unwto.org /sites/all/files/factsheet_june2015.pdf

\section{References:}

1. Zuzuk, F.V. ed. (2008). Atlas istorii kultury Volynskoi oblasti [Culture and history Atlas of Volyn' Region]. Lutsk: Volyn. Natc. Un. Im. Lesi Ukrainky, 112.

2. Kubiyovych, V. ed. (1937). Atlas Ukrainy i sumezhnyh kraiv [Ukraine and neighbouring territories]. Lviv: Naukove tovarystvo im. Shevchenka, 113.

3. Beydyk, O.O. (2001). Rekreatsiyno-turystski resursy Ukrainy: Metodologiya ta metodyka analizu, terminologiya, rayonuvannya [Recreational and tourist resources of Ukraine: Metodology and Methods of analysis, terminology, making regions]. K.: VPC "Kyiv. Un-t”, 395.

4. Bovsunovskaya, A.Ya. (2002). Geografiya turizma: Uchebnoe posobie [Tourism Geography: Study book]. Donetsk: Donet. in-t turist. biznesa, 410.

5. Volyn turystychna [Tourist Volyn] (2012). Upravlinnya kultury i turyzmu Volynskoi derzhavnoi administratsii. Available at: http:/www.cult.voladm.gov.ua/index.php?section=tour\&page=5.

6. Dorosh, A. (1996). Shveyk u Galychyni [Shveyk in Galychyna]. Galytska brama, 16, 11-13.

7. Kubiyovych, V., Zhukovskyi, A. (1977). Karta Ukrainy 1:2000000 [Map of Ukraine 1:2000000]. Munhen: Karl Wenchow GmbH.

8. Kuzyk, S.P. (2010). Teoretychni problem turyzmu: suspilno-geografichnyi pidhid: monografiya [Theoretical problems of tourism: social and geographical view: monography]. Lviv: Centr LNU imeni Ivana Franka, 254.

9. Hubilit, I., Dykyi, I. Lviv i oblast. Turystychna mapa [Lviv and Region. Tourist map]. Lviv: SPD Hubilit I.V.

10. Shabliy, O.I., Vistak, O.I., Matkovskyi, S.O. (2012). Lviv: kompleksnyi atlas [Lviv: complex atlas]. Kyiv: DNVP "Kartografiya", 192.

11. Maslyak, P.O. (2008). Rekreatsiyna geografiya: Navch. posib. [Recreational Geography: Study book]. Kyiv: Znannya, 343.

12. Petryshyn, H. (1996). Nimetski kolonii Halychyny [German colonies of Halychyna]. Lviv: Manuskrypt, 464.

13. Pro okhoronu kulturnoi spadshchyny, zakon [About cultural legacy protection, law] (2000). Vidomosti Verkhovnoi Rady (VVR), 39, 333.

14. Doptciyukh, A., Fornal, K. Tematychni shlyakhu Pidkarpatskoho voevodstva [Thematic routs of Podkarpackie voevodeship]. Zheshuv: Uryad marshalkovskyi Pidkarpatskoho voevodstva, 23.

15. Dykyi, I. (2008). Terytoriya rozselennya ukraintsiv u mezhakh suchasnoi Polshchi na seredynu XX st. 1:325000 [The territory of Ukrainians settling in modern Poland bounds in the middle of XX 1:325000]. Dnipropetrovsk: TzOV torhovyi dim "Luna Pak".

16. Shabliy, O. (2015). Suspilna geografiya u dvokh knyhah. Knyha druha. Problemy ukrainoznavstva, regionalistyky, kraeznavstva [Human Geography in two chapters. Second chapter. Problems of Ukrainian studies, region study, local history]. Lviv: LNU im. Ivana Franka, 270.

17. Województwo Lubelskie. Mapa turystyczna. 1 : 300000 / Cebryków P. i inn. - Lublin: KARTPOL, 2004.

18. Ustawa o ochronie zabytków i opiece nad zabytkami, Dz. U. Nr 162/03, poz. 1568 z późn. zm. 23 lipca 2003 r. Available at: http://www.nid.pl/pl/Dla_wlascicieli_i_zarzadcow/dla-samorzadow/ustawa\%20o\%20ochronie\%20 zabytk\%C3\%B3w\%20i\%20opiece\%20nad\%20zabytkami.pdf

19. Rejestr zabytków [List of monuments]. Available at: http://www.nid.pl/pl/Informacje_ogolne/Zabytki_w_ Polsce/rejestr-zabytkow/zestawienia-zabytkow-nieruchomych/stan\%20na\%2030.09.2016/PDK-rej.pdf

20. Wykaz zabytków nieruhomych I archeologicznych wpisanych do Rejestru zabytków w 2016 [Enumeration of immovable and archaeological monuments entered in List of monuments in 2016]. Available at: http://wkz.lublin.pl/images/stories/Obwieszczenie_nr1_2016.pdf

21. Pro zanesennya obyektiv kulturnoi spadshchyny natsionalnoho znachennya do Derzhavnoho reyestru nerukhomykh pamyatok Ukrainy [About cultural heritage objects entering in National List of immovable monuments of Ukraine]. Available at: http://zakon5.rada.gov.ua/laws/show/1805-14

23. Global Report on Food Tourism. Available at: http://cf.cdn.unwto.org/sites/all/files/factsheet_june2015.pdf 